\title{
Udder firmness as a possible indicator for clinical mastitis
}

\author{
A. Rees, C. Fischer-Tenhagen, and W. Heuwieser ${ }^{1,2}$ \\ Clinic for Animal Reproduction, Faculty of Veterinary Medicine, Freie Universität Berlin, Koenigsweg 65, 14163 Berlin, Germany
}

\begin{abstract}
Swelling of the mammary gland is an important sign to detect clinical mastitis $(\mathrm{CM})$ in dairy cows. The overall objective of this study was to evaluate if udder firmness can be used as a cow-side indicator for mastitis and to evaluate how CM affects firmness within $14 \mathrm{~d}$ after diagnosis. A dynamometer was used to objectively determine udder firmness before and after milking in 45 cows with CM and 95 healthy cows. Udder firmness of both hind quarters was measured daily on 3 locations (upper, middle, lower measuring point) from the day of mastitis diagnosis until $\mathrm{d} 7$ and again on $\mathrm{d} 14$. Firmness of the middle measuring point was highest before and after milking in all cows. Udder firmness before milking was similar in quarters without and with CM. Subsequently, we concentrated on firmness measured on the middle point after milking. After milking, quarters with $\mathrm{CM}$ were firmer than healthy quarters. An increase of firmness of a quarter with mastitis did not affect firmness of the healthy neighboring quarter, nor did firmness of all healthy quarters differ. One firmness value per cow [i.e., $\Delta$ firmness (difference in udder firmness between both hind quarters)] was used for all further calculations. After fitting a generalized mixed model, $\mathrm{CM}$ affected $\Delta$ firmness in all cases. In multiparous cows, $\Delta$ firmness was also affected by continuous milk yield per day and DIM. Firmness thresholds for detection of $\mathrm{CM}$ were calculated using receiver operation characteristic curves. The threshold for detection of $\mathrm{CM}$ using $\Delta$ firmness was $0.282 \mathrm{~kg}$ (area under the curve: 0.722 , sensitivity: $64.3 \%$, specificity: $89.7 \%$ ) and 0.425 $\mathrm{kg}$ (area under the curve: 0.817, sensitivity: 62.5\%, specificity: $96.7 \%$ ) in primiparous cows and multiparous cows, respectively. Linear mixed-model ANOVA were used to evaluate how $\mathrm{CM}$ affects udder firmness within $14 \mathrm{~d}$ after diagnosis. Cows with CM had a higher
\end{abstract}

\footnotetext{
Received August 30, 2016.

Accepted November 22, 2016.

${ }^{1}$ Current address: Department of Population Medicine and Diagnostic Sciences, College of Veterinary Medicine, Cornell University, Ithaca, NY 14853.

${ }^{2}$ Corresponding author: w.heuwieser@fu-berlin.de
}

$\Delta$ firmness compared with cows without CM throughout the $14 \mathrm{~d}$ after the mastitis diagnoses. Parity had an effect on $\Delta$ firmness. Depending on systemic signs of sickness, mastitic cows were divided into cows having mild to moderate $(\mathrm{n}=21)$ or severe mastitis $(\mathrm{n}=24)$. Cows with severe mastitis suffered from a firmer udder on all measuring days. Bacteriological cure was defined based on 2 milk samples taken at 7 and $14 \mathrm{~d}$ after enrollment. An effect of parity and bacteriological cure on $\Delta$ firmness of cows with $\mathrm{CM}$ did not exist within the $14 \mathrm{~d}$. Cows not clinically cured showed an increased $\Delta$ firmness of $0.560 \mathrm{~kg}$ compared with cured cows. In conclusion, udder firmness can be a useful indicator for CM. Further research is warranted to evaluate if udder firmness can be used as a predictor for the prognosis of a CM or the cure of inflammation.

Key words: udder firmness, dynamometer, clinical mastitis, diagnosis

\section{INTRODUCTION}

Mastitis is a highly relevant disease (Hertl et al., 2011, 2014) and the most common indication for the use of antimicrobial agents in dairy cows (Thomson et al., 2008). Approximately $50 \%$ of all parenterally administered antibiotics are used for the therapy of clinical mastitis (CM; Pol and Ruegg, 2007). A prudent use of antibiotics, however, has been emphasized and advocated as the issue is a top priority public health challenge (Oliver et al., 2011; Machado et al., 2014).

Detection of the infected quarter, however, precedes an antibiotic therapy of CM (Oliver et al., 2011). Clinical symptoms to detect $\mathrm{CM}$ include changes in milk characteristics and redness, swelling, and warming of the infected quarter. Besides checking the milk for abnormalities, determination of udder firmness is a plausible and practical method to diagnose this disease as an increased firmness is a manifestation of the swelling (i.e., increase of udder tissue consistency). Veterinarians and farmers frequently base treatment decisions on clinical symptoms of the udder (Swinkels et al., 2015). Udder firmness, however, seems to be a difficult variable to determine correctly (Fossing et al., 2006). Also, no data are available to quantitatively define a healthy udder using specific thresholds for udder firmness. Be- 
sides a description in a textbook (Rosenberger et al., 1990), data are not available to objectively differentiate healthy from affected udders. Furthermore, farmers' insecurity in mastitis therapy and frequent occurrence of extended treatment of CM has been described (Swinkels et al., 2015). Therefore, more research is warranted on the evolution of clinical criteria (Swinkels et al., 2015) and specific guidelines are needed to provide differentiation between cows without and with CM. The timely detection of signs of CM would also allow shorter and more effective drug treatments (Trevisi et al., 2014).

It was demonstrated (Bertulat et al., 2012; Rees et al., 2014) that udder firmness in healthy cows could be determined with a good repeatability by trained observers by using an electronic handheld device (i.e., a dynamometer). Furthermore, a preliminary comparison between cows with and without CM indicated that the milking induced decrease of udder firmness was lower in mastitic quarters (Rees et al., 2013). In this study, however, cows with CM were included on different days relative to the onset of infection ( 0 to $72 \mathrm{~d}$ ). Thus, different stages of CM were included confounding the results.

Therefore, the overall objective of this study was to evaluate if udder firmness can be used as a cow-side indicator for mastitis. Specifically, we set out to (1) establish firmness thresholds for the differentiation between cows without and with CM and (2) to evaluate how CM affects udder firmness within $14 \mathrm{~d}$ after diagnosis.

\section{MATERIALS AND METHODS}

\section{Housing and Animals}

The study was conducted from April 2014 to August 2014 on a commercial dairy farm milking 1,200 Holstein-Friesian dairy cows in Sachsen-Anhalt, Germany. Cows were housed in a freestall barn with slatted floors and cubicles equipped with rubber mats. They were grouped regarding parity (primiparous and multiparous) throughout the whole lactation. Cows were fed a TMR consisting of $38.5 \%$ corn silage, $35.9 \%$ concentrate mineral mix, $22.5 \%$ grass silage, and $3.1 \%$ barley straw. Feed was delivered via a conveyer belt system 10 times per day. All cows had ad libitum access to water. Cows were milked 3 times a day during 3 milking shifts from 0700 to $1400 \mathrm{~h}$ and 1500 to $2200 \mathrm{~h}$ and 2300 to $0600 \mathrm{~h}$ in a 52 -stall external rotary milking parlor (Lemmer-Fullwood GmbH, Lohmar, Germany). Each stall was equipped with a digital display that reported milk yield per cow and current milking. The average 305-d milk yield was $10,147 \mathrm{~kg}(4.04 \%$ fat and $3.35 \%$ protein). During the study period, average SCC was
250,000 per $\mathrm{mL}$ of bulk tank milk and incidence of CM was 24 cases per 100 cow-years.

\section{Mastitis Management}

The milking personnel checked all cows before each milking for signs of CM by visually examining foremilk on a dark surface as the standard procedure. An udder quarter was diagnosed as having CM when clots or flakes in foremilk samples were observed. Based on a severity classification system described previously (Oliveira et al., 2013), such a case was defined as a mild to moderate case of CM. Because Streptococcus uberis was known to be the dominant pathogen causing $\mathrm{CM}$ on this farm, the infected quarter was treated with an intramammary infusion of 3,000,000 IU of procaine benzyl penicillin (Procain-Penicillin-G Injektor aniMedica, $300 \mathrm{mg} / \mathrm{mL}$, Selactavet, Weyarn-Holzolling, Germany) every $24 \mathrm{~h}$ for 3 consecutive days. When signs of generalized sickness such as reduced feed intake, dullness, or a rectal temperature above $39.5^{\circ} \mathrm{C}$ were present, the case was considered severe (Oliveira et al., 2013) and intramammary treatment was complemented by parenterally administered antibiotic and nonsteroidal anti-inflammatory drugs. Specifically, 10,000 IU of penethamate hydriodide (Mamyzin, Boehringer Ingelheim $\mathrm{GmbH}$, Ingelheim, Germany) and 2.0 $\mathrm{mg}$ of marbofloxacin (Odimar $100 \mathrm{mg} / \mathrm{mL}$, Animalcare Limited, Dunnington, United Kingdom) and $0.5 \mathrm{mg}$ of meloxicam (Melovem $20 \mathrm{mg} / \mathrm{mL}$, Dopharma Research B.V., Raamsdonksveer, the Netherlands) or $2.2 \mathrm{mg}$ of flunixin meglumine (Finadyne, MSD Animal Health GmbH, Luzern, Switzerland) per kilogram of BW were administered intramuscularly or intravenously in the latter case. Additional intramammary treatment was administered (and if necessary changed) according to the culture results and susceptibility testing. An intramammary infusion of $200 \mathrm{mg}$ of cefalexin and 100,000 IU of kanamycin (Ubrolexin, Boehringer Ingelheim Vetmedica GmbH, Ingelheim/Rhein, Germany) or 100 mg of cefoperazon (Peracef, Zoetis Österreich GmbH, Wien, Austria) twice in a period of $24 \mathrm{~h}$ completed treatment of mastitis caused by pathogens not susceptible to procaine benzyl penicillin. All treatments were documented in the on-farm computer program (Herde, Agrosoft, Paretz, Germany).

Cows with signs of CM diagnosed by the milking personnel were moved to the mastitis pen. They were reintroduced into the production groups when the withdrawal period for milk had expired and the appearance of the milk had returned to normal. Cubicles in the mastitis pen were equipped with rubber mats and covered by a 10-cm layer of recycled manure solids from the on-site biogas plant. All cubicles were cleaned 

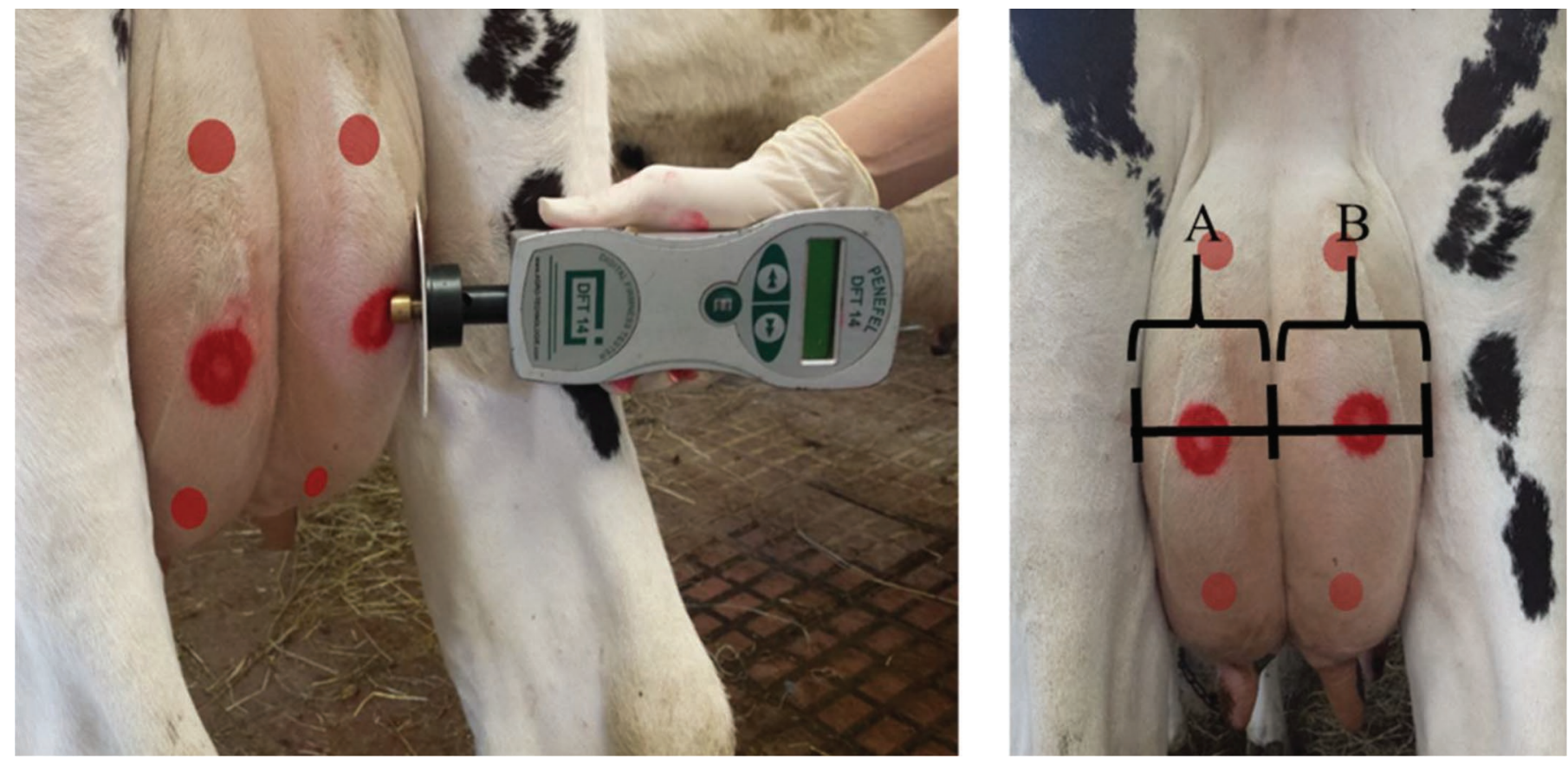

Figure 1. Measuring udder firmness using a dynamometer (Penefel DFT 14, Agro Technologies, Forges-les-Eaux, France). Measuring points were marked with livestock paint crayons (Raidex, Dettingen, Germany). Difference in udder firmness between both hind quarters $(\Delta$ firmness) was calculated by subtracting the firmness of the left (A) and the right (B) quarter measured after milking. Udder morphology was evaluated by measuring the width and length of both hind quarters. A symmetric udder was defined as having a difference in width and length between both hind quarters $<2 \mathrm{~cm}$. Color version available online.

manually 3 times a day and the layer was topped once a week.

\section{Sample Size and Enrollment}

Sample size calculation was performed with WinEpiscope 2.0 (www.winepi.net/; University of Zaragoza, Zaragoza, Spain) using a 95\% confidence interval and $80 \%$ of power (Thrusfield et al., 2001). The minimum number of cows to be included was estimated based on previously estimated mean udder firmness after milking (Rees et al., 2013) of cows without $(0.700 \mathrm{~kg})$ and with CM $(1.300 \mathrm{~kg})$. A 2 -sided test was selected with an $\alpha$ of 0.05 and a power $(1-\beta)$ of 0.80 . A minimum sample size of 38 cows per group was calculated.

Cows were enrolled when the milking personnel observed CM in one of the hind quarters. Day of enrollment was considered as d 0. Quarter milk samples were collected immediately before milking from both hind quarters. Six measuring points were marked and udder firmness was determined as described below. Also, rectal temperature was measured and actual milk yield recorded. Udder morphology (i.e., the length from the teat base to the rear udder attachment and the width of both hind quarters individually, Figure 1) was determined using a measuring tape. To create an appropriate negative control group, 2 randomly selected cows entering the milking parlor within 10 min after the cow with CM were enrolled and processed the same way. These 2 cows had to be free from signs of CM. After milking, the cow with $\mathrm{CM}$ was moved to the mastitis pen, whereas the cows without CM remained in their original group.

\section{Udder Firmness Measurement and Sampling}

Udder firmness was determined by using a dynamometer (Figure 1, Penefel DFT 14, Agro Technologies, Forges les Eaux, France). The dynamometer is equipped with a $15-\mathrm{mm}$ measuring tip connected to a pressure sensor. A plastic plate $(70 \times 100 \mathrm{~mm})$ installed $20 \mathrm{~mm}$ behind and parallel to the surface of the measuring tip defines the penetration depth. It measures the maximum weight in kilograms bearing on the measuring tip. The measuring range is 0.05 to $14 \mathrm{~kg}$, with a precision of $\pm 0.04 \mathrm{~kg}$ according to the manufacturer (Bertulat et al., 2012). In total, 4 dynamometers were used considering the standard operation procedure described by Bertulat et al. (2012). In brief, the cow had to stand with all 4 legs on a level surface and the dynamometer needed to be held perpendicular to the quarter surface during the whole measurement. After 5 consecutive measurements performed within $10 \mathrm{~s}$ the dynamometer displayed the arithmetic mean 
and coefficient of variation. Values with a coefficient of variation exceeding $10 \%$ were discarded and the measurement repeated. A coefficient of variation exceeding $10 \%$ could be caused by, for example, a movement of the cow before the 5 consecutive measurements were concluded. Regardless of the health status of the udder quarter, firmness was always measured and recorded on the left hind quarter first, followed by the right hind quarter. All dynamometers were validated before the field trial started. Three observers conducted firmness measurements. All observers had participated in previous training sessions and udder firmness studies (Rees et al., 2013, 2014), and thus were experienced in measuring udder firmness. One observer (first author), however, conducted almost all measurements throughout the 5-mo study period except during a 2 -wk break.

According to the standard operating procedure for the dynamometer (Bertulat et al., 2012), to quantify effects of location within a given quarter and between quarters, the measuring points were located in the center of the upper, middle, and lower third of both hind quarters, respectively (Figure 1). These points were marked with livestock paint crayons (Raidex, Dettingen, Germany) to ensure a consistent measurement location within the udder during the whole study period.

Quarter milk samples were aseptically collected immediately before routine milking following procedures described by the National Mastitis Council (Hogan et al., 1999). Milk samples immediately were cooled down to a temperature of $8^{\circ} \mathrm{C}$ and transported to a commercial milk laboratory within $2 \mathrm{~d}$.

\section{Laboratory Procedures}

Milk samples submitted to the laboratory were cultured using standard microbiological methods (Hogan et al., 1999). Briefly, a volume of $0.01 \mathrm{~mL}$ of milk was inoculated on esculin blood agar (Oxoid Deutschland $\mathrm{GmbH}$, Wesel, Germany) and the plate was incubated at $37^{\circ} \mathrm{C}$. Plates were examined for growth at 24 and $48 \mathrm{~h}$. Bacteria were identified by colony morphology and Gram stain. For gram-positive cocci, catalase tests were performed to distinguish catalase-negative Staphylococcus spp. from catalase-positive Staphylococcus spp. Streptococci were differentiated by using a commercial test kit (Patho Dxtra Strep Grouping Kit, Oxoid Deutschland GmbH, Wesel, Germany) and growth on esculin blood agar plates. Catalase-positive gram-positive cocci were further identified using a coagulase test and hemolysis patterns. Gram-positive bacilli were further identified using the catalase test and biochemical reactions as needed. Gram-negative bacilli were identified by the oxidase test and the EnteroPluritest (Becton, Dickinson and Company, Heidelberg, Germany).
Contaminated samples were defined as a mixture of at least 3 environmental type organisms without isolation of a major mastitis pathogen. Antimicrobial susceptibility of every grown bacterium was tested using the agar disk diffusion method. The SCC analysis of each quarter milk sample was performed using a DeLaval cell counter (DeLaval GmbH, Glinde, Germany).

\section{Experimental Design}

Each cow was re-examined daily until d 7 after mastitis was diagnosed and examined again on d 14 [i.e., on all measuring days $(n=9)$ ]. On each of these days, udder firmness and rectal temperature were determined and actual milk yield recorded. Additionally, the milking personnel checked the milk of all cows for abnormalities. Udder firmness was assessed in the barn 1.4 $\pm 1.2 \mathrm{~h}$ before milking and immediately after milking while cows were still in the milking parlor. When a cow was enrolled in the first, second, or third milking shift, all subsequent measurements for this cow were also conducted during the first, second or third shift, respectively. Additionally, on d 0, 7, and 14, measurements of udder morphology were determined after milking and milk samples collected as described for $\mathrm{d} 0$.

\section{Clinical and Bacteriological Cures}

Bacteriological and clinical cures were defined as previously described (Schukken et al., 2013). In brief, a quarter that was infected at the beginning of treatment was defined as bacteriologically cured when the organism that was identified in the milk sample on $\mathrm{d} 0$ was not present in the samples of both d 7 and 14. Clinical cure was defined as the presence of normal milk on both $\mathrm{d} 7$ and 14 .

\section{Data Processing and Statistical Analysis}

Data were entered into Excel (version 2010, Microsoft, Redmond, WA) and statistical analyses performed with SPSS for Windows (version 20.0, SPSS Inc., Munich, Germany) and MedCalc (version 12.5.0.0, MedCalc software, Mariakerke, Belgium). Statistical significance was set at $P<0.05$ and a trend for significance was set at $P<0.10$. All data were tested for normal distribution via visual examination of histograms.

Data regarding parity (primiparous, multiparous) and Gram staining characteristics (gram-negative, gram-positive, bacteriologically negative) were categorized. Udder morphology values were used to define a symmetric (i.e., difference in width and length between both hind quarters $<2 \mathrm{~cm}$ ) or asymmetric (difference in width and length between both hind quarters $\geq 2 \mathrm{~cm}$ ) udder. The SCC values were $\log _{10}$ transformed. 
Udder firmness before and after milking as well as milking-induced decrease in udder firmness in cows without and with CM was compared using a Wilcoxon sign rank test. We first compared firmness within a given quarter (i.e., firmness within the 3 different locations) measured before and after milking using a Friedman test to reduce clustering of data on the quarter level and to detect possible influence of the location on firmness within a given quarter. A Wilcoxon sign rank test was assessed to further compare firmness of the middle measuring point with firmness of the upper and lower measuring point, respectively. The results of the latter calculations indicated that udder firmness measured at the middle measuring point was least variant. Therefore, we used the middle measuring point and udder firmness after milking for all subsequent calculations. To establish firmness thresholds (i.e., first objective), only values measured on d 0 were used for the comparison between cows without and with CM. First, a Wilcoxon sign rank test was used to compare firmness of both hind quarters within all cows. Second, we compared udder firmness of all healthy quarters of healthy cows using a Kruskal-Wallis test. Third, firmness of all healthy hind quarters of healthy cows was compared with that of healthy hind quarters of cows with CM using a Kruskal-Wallis test to evaluate the effect of a CM on the firmness of the healthy neighboring quarter. To further reduce data clustering on the cow level (i.e., to have 1 instead of 2 firmness values per cow), difference in udder firmness between both hind quarters measured on the middle measuring point of a given cow after milking ( $\Delta$ firmness) was calculated and compared between cows without and with CM using a Kruskal-Wallis test.

Influencing factors on udder firmness were tested by generating a generalized mixed model with $\Delta$ firmness after milking as the dependent variable. Tested factors were CM (yes, no), continuous milk yield per day, DIM, parity (primiparous, multiparous), Gram staining characteristics (gram-negative, gram-positive, bacteriologically negative), and symmetry between hind udder quarters (yes, no). Interactions were tested between CM and DIM, parity, and continuous milk yield per day, respectively. The statistical model was built according to the model-building strategies described previously (Dohoo et al., 2009; Bertulat et al., 2013). The significance level was set at $P \leq 0.05$.

A receiver operating characteristic (ROC) curve was calculated to compare the diagnostic performance of udder firmness for the detection of CM. Interpretation of ROC curves was based on the area under the ROC curve as well as the positive predictive values and negative predictive values. Parameters tested were $\Delta$ firmness measured with the dynamometer after milking on $\mathrm{d} 0$. The best thresholds were chosen based on the highest sum of sensitivity and specificity. Because results obtained from the mixed model indicated an influence of parity on udder firmness, we further conducted ROC analyses for primiparous and multiparous cows separately. To guarantee a minimum sensitivity of approximately $70 \%$ for a $95 \%$ confidence interval, a sensitivity of $80 \%$ and specificity of $99 \%$ were proposed for automatic in-line CM detection by the Annex of an International Standard ISO/FDIS 20966 of the International Organization for Standardization (ISO, 2007).

Our second objective was to evaluate how CM affects udder firmness measured with the dynamometer after milking within $14 \mathrm{~d}$ after diagnosis. Therefore, 2 linear mixed-model ANOVA were constructed to evaluate the effect of CM on udder firmness during the first $14 \mathrm{~d}$ after mastitis diagnosis. For the first model, $\Delta$ firmness was the dependent variable with day (d 0 to 7 and 14, $\mathrm{n}$ $=9)$ as the repeated measure. All cows $(\mathrm{n}=140)$ were included. Tested factors were CM (yes, no), continuous milk yield per day, DIM, and parity (primiparous, multiparous). The random effect of cow was included in the model. Moreover, the diagonal covariance structure was used. We collected data regarding Gram staining characteristics on $\mathrm{d} 0,7$, and 14 . Therefore, we re-fitted the first model using day (d 0,7 , and $14, \mathrm{n}=3$ ) as the repeated measure and included Gram staining characteristics with the tested factors mentioned above. A second model was built to test the influence of severity of $\mathrm{CM}$ (mild to moderate CM, severe CM) including only cows with CM $(\mathrm{n}=45)$. Fixed factors were parity (primiparous, multiparous), severity (mild to moderate $\mathrm{CM}$, severe $\mathrm{CM}$ ), and bacteriological and clinical cure. Models were built according to the model-building strategies described previously (Dohoo et al., 2009; Bertulat et al., 2013). Data were $\log _{10}$ transformed before analysis to achieve normal distribution, but backtransformed values are reported.

Because SCC was highly correlated with CM during the first step of the model building process, we could not include SCC values in the final models. We therefore checked the difference of $\log _{10}$-transformed SCC in quarters without and with $\mathrm{CM}$ as the dependent variable on $\mathrm{d} 0,7$, and 14 in a linear mixed-model ANOVA. All quarters $(\mathrm{n}=235)$ were included. In detail, day $(\mathrm{d} 0,7$, and $14 ; \mathrm{n}=3$ ) was the repeated measure; $\mathrm{CM}$ (yes, no), continuous milk yield per day, DIM and parity (primiparous, multiparous) were fixed factors and the random effect of cow were included in this model. The model was built according to the model-building strategies described above. 


\section{RESULTS}

In total, 140 cows (21 with mild to moderate CM, 24 with severe $\mathrm{CM}$, and 95 without $\mathrm{CM}$ ) were enrolled. Cows without and with $\mathrm{CM}$ were both primiparous (n $=35, \mathrm{n}=13)$ and multiparous $(\mathrm{n}=60, \mathrm{n}=32$, respectively). Healthy and CM cows were $163 \pm 103$ and 151 \pm 104 DIM (mean \pm SD), respectively.

\section{Milk Samples and Cure}

Milk samples of the 45 quarters with CM were bacteriologically negative and contained gram-positive and gram-negative bacteria in 11, 24, and 10 cases, respectively. Out of the 45 cows with $\mathrm{CM}, 21$ cows suffered from mild to moderate $\mathrm{CM}$ and 24 cows from severe CM. Milk samples of cows with mild to moderate CM were bacteriologically negative and contained gram-positive and gram-negative bacteria in 3,11 , and 7 cases, respectively. In cows with severe CM, milk samples were bacteriologically negative and contained gram-positive and gram-negative bacteria in 8, 13, and 3 cases, respectively. The distribution of Gram stain characteristics was similar ( $P=0.144$, chi-squared test) in cows with mild to moderate and cows with severe CM.

Cases were only eligible for bacteriological cure analysis when the treated quarter was infected at the time of enrollment into the study. This was the case in 34 out of 45 quarters with CM (76\%). Bacteriological cure was observed in 17 of these 34 cases (50\%). In detail, 11 out of 21 cows with mild to moderate CM $(52 \%)$ and 6 out of 24 cows with severe CM (25\%) were bacteriologically cured. Clinical cure was observed for 29 out of all 45 cows with CM (64\%). Fourteen out of 21 cows with mild to moderate CM $(67 \%)$ and 15 out of 24 cows with severe CM (63\%) were clinically cured. Clinical cure was $45 \%$ for the quarters bacteriologically negative at enrollment, $46 \%$ for gram-positive bacteria, and $60 \%$ for gram-negative bacteria.

\section{Udder Firmness}

Overall range of udder firmness values measured with the dynamometer $(\mathrm{n}=7,560)$ was 0.300 to 11.390 $\mathrm{kg}$. Before milking, median udder firmness in quarters without and with $\mathrm{CM}$ was $1.867 \mathrm{~kg}$ [interquartile range (IQR): 1.243 to $2.671 \mathrm{~kg}, \mathrm{n}=6,340]$ and $1.948 \mathrm{~kg}$ (IQR: 1.213 to $2.819 \mathrm{~kg}, \mathrm{n}=1,220)$, respectively $(P$ $=0.675)$. After milking, udder firmness differed $(P<$ $0.001)$ between quarters without $(0.636 \mathrm{~kg}$, IQR: 0.514 to $0.783 \mathrm{~kg})$ and with CM (1.036 kg, IQR: 0.704 to $1.702 \mathrm{~kg}$ ). Median milking-induced decrease of udder firmness was $1.207 \mathrm{~kg}$ (IQR: 0.649 to $1.914 \mathrm{~kg}, P<$
0.001 ) in quarters without $\mathrm{CM}$ and $0.745 \mathrm{~kg}$ (IQR: 0.292 to $1.359 \mathrm{~kg} ; P<0.001)$ in quarters with $\mathrm{CM}$.

Firmness between the 3 locations within a given quarter differed $(P<0.001)$ both in quarters without ( $\mathrm{n}=1,848$ and 2,081$)$ and with $\mathrm{CM}(\mathrm{n}=356$ and 399$)$ measured before and after milking, respectively. Before milking, median udder firmness of the upper and lower measuring point was $23.6 \%(1.825 \mathrm{~kg}$, IQR: 1.260 to $2.570 \mathrm{~kg}, P<0.001)$ and $59.4 \%(1.420 \mathrm{~kg}$, IQR: 0.950 to $2.100 \mathrm{~kg}, P<0.001)$ lower compared with the middle point in quarters without CM $(2.390 \mathrm{~kg}$, IQR: 1.770 to $3.200 \mathrm{~kg}$ ), respectively. Compared with the middle point in quarters with $\mathrm{CM}(2.400 \mathrm{~kg}$, IQR: 1.643 to $3.340 \mathrm{~kg}$ ), firmness of the upper and lower measuring point was $33.1 \%(1.605 \mathrm{~kg}$, IQR: 1.070 to $2.248 \mathrm{~kg}, P<0.001)$ and $30.0 \%(1.680 \mathrm{~kg}$, IQR: 1.103 to $2.758 \mathrm{~kg}, P<0.001)$ lower, respectively. After milking, median firmness of the upper measuring point was $20.6 \%(0.573 \mathrm{~kg}$, IQR: 0.464 to $0.699 \mathrm{~kg}, P<0.001)$ lower and firmness of the lower measuring point was $13.6 \%(0.624 \mathrm{~kg}$, IQR: 0.499 to $0.767 \mathrm{~kg}, P<0.001)$ lower than the middle point $(0.722 \mathrm{~kg}$, IQR: 0.600 to $0.864 \mathrm{~kg}$ ) in quarters without CM (Figure 2). In quarters with CM, median firmness of the upper measuring point was $39.1 \%$ (0.791 kg, IQR: 0.588 to $1.135 \mathrm{~kg}, P$ $<0.001$ ) lower than firmness of the middle measuring point $(1.297 \mathrm{~kg}$, IQR: 0.844 to $1.959 \mathrm{~kg}, P<0.001$; Figure 2). No difference was found in firmness of the latter with the lower measuring point $(1.203 \mathrm{~kg}$, IQR: 0.771 to $2.053 \mathrm{~kg}, P=0.257$; Figure 2).

On d 0 after milking, firmness of both hind quarters within a cow without $\mathrm{CM}$ did not differ $(P=0.369)$. Firmness within a cow with a mastitic and a healthy quarter, however, differed (Figure 3; $P<0.001$ ). Median udder firmness of all healthy quarters [i.e., all right $(0.770 \mathrm{~kg}$, IQR: 0.629 to $0.935 \mathrm{~kg} ; \mathrm{n}=95 ; P=$ $0.931)$ and left $(0.745 \mathrm{~kg}$, IQR: 0.624 to $0.885 \mathrm{~kg} ; \mathrm{n}=$ $95 ; P=0.349)$ healthy quarters of healthy cows] was similar after milking (Figure 3$)$. No difference $(P=$ 0.419 ) was found in firmness of all healthy quarters of healthy cows $(\mathrm{n}=190 ; 0.755 \mathrm{~kg}$, IQR: 0.629 to 0.908 $\mathrm{kg}$ ) compared with healthy quarters of cows with CM (Figure $3 ; \mathrm{n}=45 ; 0.704 \mathrm{~kg}$, IQR: 0.617 to $1.024 \mathrm{~kg}$ ).

Median $\Delta$ firmness on $\mathrm{d} 0$ differed $(P<0.001)$ between cows without $(0.098 \mathrm{~kg}$, IQR: 0.030 to 0.216 $\mathrm{kg}$ ) and with CM (0.756 kg, IQR: 0.170 to $1.914 \mathrm{~kg}$; Figure 4). Gram staining characteristics and symmetry between hind udder quarters had no effect on $\Delta$ firmness after milking. These variables were excluded from the final model because they resulted in univariate models with $P \geq 0.2$. Interactions between $\mathrm{CM}$ and DIM $(P=0.008), \mathrm{CM}$ and parity $(P=0.036)$, and $\mathrm{CM}$ and continuous milk yield per day $(P=0.025)$ affected udder firmness. Specifically, the difference of $\Delta$ 


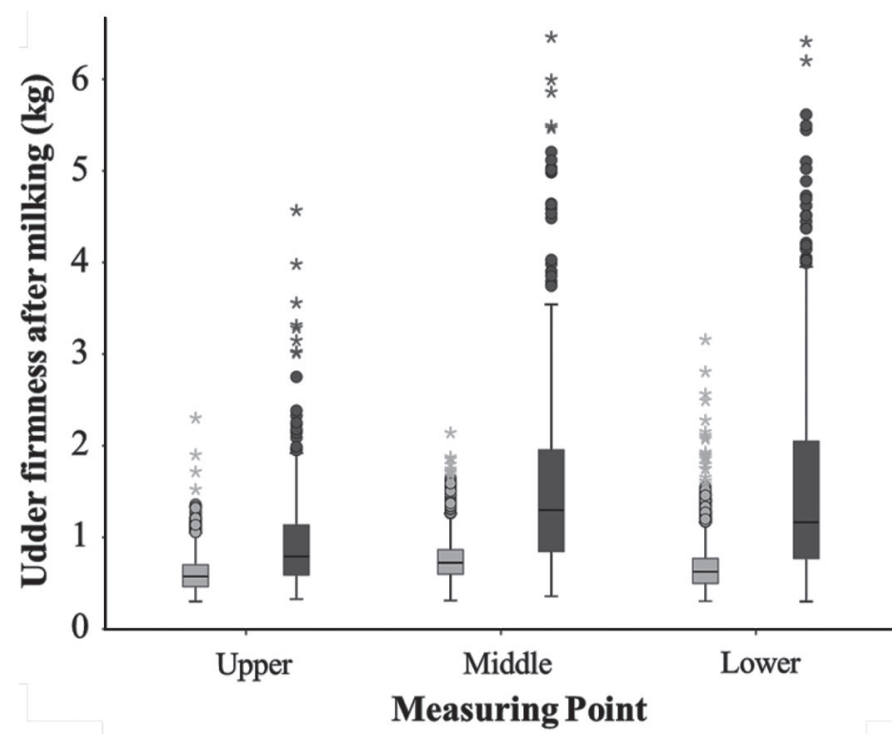

Figure 2. Udder firmness $(\mathrm{kg})$ measured after milking on 3 locations (upper, middle, lower measuring point) within a given udder quarter in cows without $(\mathrm{n}=95$, light gray bars) and with clinical mastitis ( $\mathrm{n}=45$, dark gray bars) using a dynamometer. The heavy black line inside each box marks the median; the bottom and top of the boxes are the first and third quartiles; whiskers end at the smallest and largest statistical values that are not outliers or extreme values. Circles and asterisks indicate outliers and extreme outliers, respectively.

firmness between cows without and with CM decreased with increasing DIM and continuous milk yield per day (Figure 5). To analyze the interaction between CM and parity, an additional model was calculated considering cows without and with $\mathrm{CM}$ as well as primiparous and multiparous cows, respectively. Solely CM $(P<0.001)$ affected $\Delta$ firmness after milking using all cows and primiparous cows. Other tested factors (i.e., continuous milk yield per day, DIM, parity) had no effect on $\Delta$ firmness in both cows without and with CM. In primiparous cows, continuous milk yield per day and DIM had no effect on $\Delta$ firmness. In multiparous cows, $\Delta$ firmness after milking was affected by $\mathrm{CM}(P<0.001)$, continuous milk yield per day $(P<0.001)$, and DIM $(P<0.001)$.

\section{Thresholds of Udder Firmness}

Results of a ROC analysis to determine thresholds for $\Delta$ firmness delivering the best combination of sensitivity and specificity to differentiate healthy from mastitic cows are shown in Table 1 . Thresholds calculated for $\Delta$ firmness to achieve ideal sensitivity of $80 \%$ (ISO, 2007) by using our data and visual judgement of foremilk as the gold standard were $>0.149 \mathrm{~kg}$ for all cows, $>0.020$ $\mathrm{kg}$ for primiparous cows, and $>0.153 \mathrm{~kg}$ for multiparous

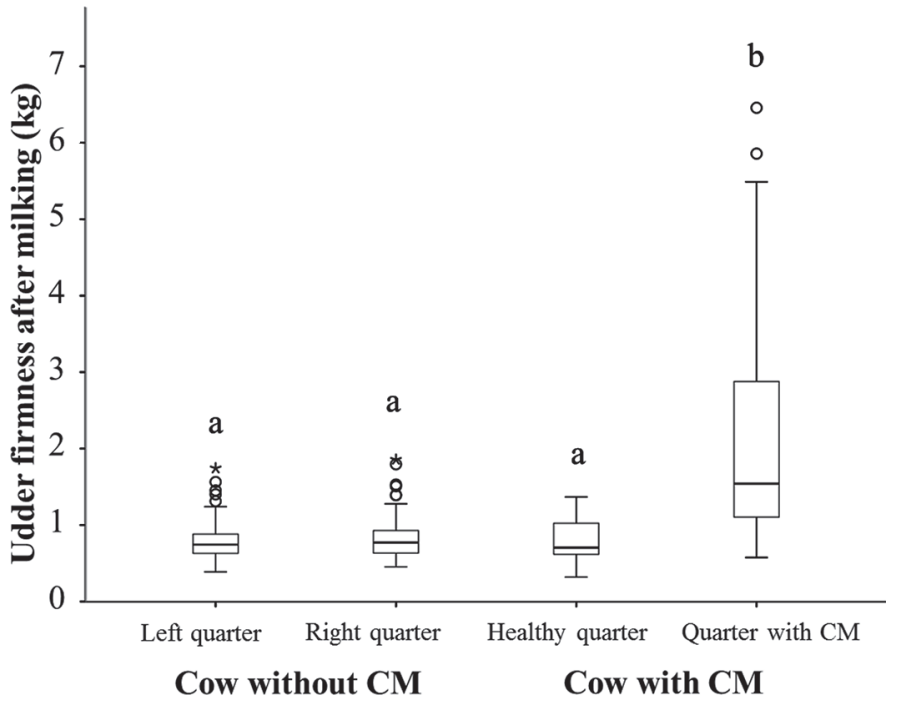

Figure 3. Udder firmness $(\mathrm{kg})$ of hind quarters in cows without clinical mastitis $(\mathrm{CM}, \mathrm{n}=95)$ and healthy and mastitic hind quarters in cows with CM $(\mathrm{n}=45)$ using a dynamometer. Values with different lowercase letters differ $(P<0.001)$. The heavy black line inside each box marks the median; the bottom and top of the boxes are the first and third quartiles; whiskers end at the smallest and largest statistical values that are not outliers or extreme values. Circles and asterisks indicate outliers and extreme outliers, respectively.

cows. For an ideal specificity of $99 \%$ (ISO, 2007), one identical threshold of $>0.831 \mathrm{~kg}$ should be used for all cows, primiparous cows, and multiparous cows.

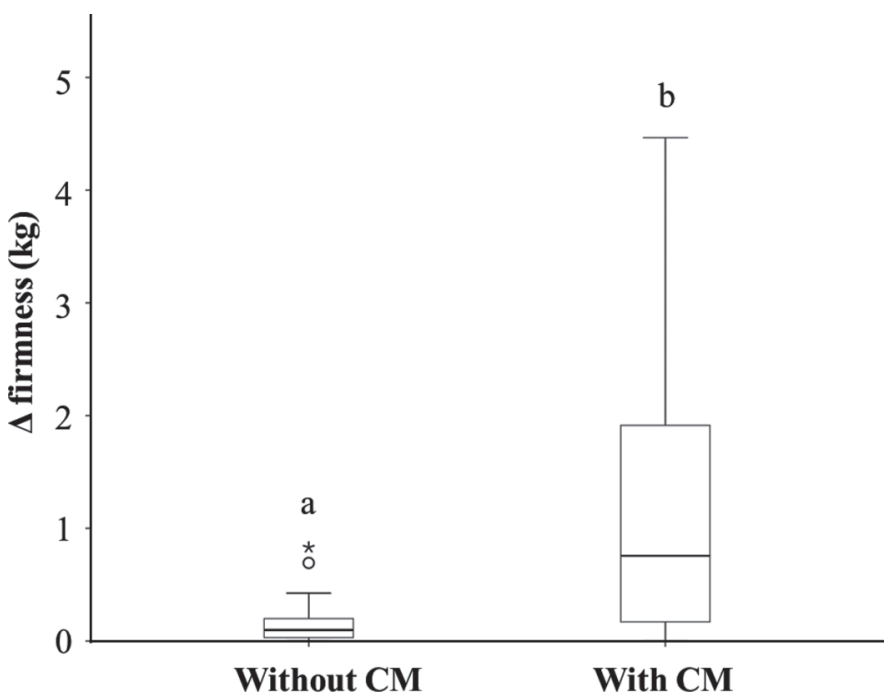

Figure 4. Difference in udder firmness between both hind quarters $(\Delta$ firmness, $\mathrm{kg})$ in cows without $(\mathrm{n}=95)$ and with clinical mastitis $(\mathrm{CM}, \mathrm{n}=45)$ measured with a dynamometer after milking. Values with different lowercase letters differ $(P<0.001)$. The heavy black line inside each box marks the median; the bottom and top of the boxes are the first and third quartiles; whiskers end at the smallest and largest statistical values that are not outliers or extreme values. Circles and asterisks indicate outliers and extreme outliers, respectively. 
Table 1. Diagnostic test characteristics for thresholds of difference of udder firmness between both hind quarters of a given cow in $\mathrm{kg}$ ( $\Delta$ firmness) to identify cows with clinical mastitis measured by a dynamometer considering different groups of enrolled cows [i.e., all cows $(\mathrm{n}=140)$, primiparous cows $(\mathrm{n}=48)$, and multiparous cows $(\mathrm{n}=92)]$

\begin{tabular}{lccc}
\hline & \multicolumn{3}{c}{ Enrolled cows } \\
\cline { 2 - 4 } Test characteristic & All cows & $\begin{array}{c}\text { Primiparous } \\
\text { cows }\end{array}$ & $\begin{array}{c}\text { Multiparous } \\
\text { cows }\end{array}$ \\
\hline Threshold of $\Delta$ firmness $(\mathrm{kg})$ & 0.425 & 0.282 & 0.425 \\
AUC $^{1}$ & 0.809 & 0.722 & 0.817 \\
Sensitivity & 60.00 & 64.29 & 62.50 \\
Specificity & 97.89 & 89.74 & 96.67 \\
Positive predictive value & 93.1 & 69.2 & 90.9 \\
Negative predictive value & 83.8 & 87.5 & 82.9 \\
\hline
\end{tabular}

${ }^{1} \mathrm{AUC}=$ area under the receiver operating characteristic curve.

\section{Udder Firmness Within 2 Wk After Diagnosis}

An effect of CM on udder firmness after milking was observed throughout the first $14 \mathrm{~d}$ after mastitis diagnosis. Cows with CM had a higher $\Delta$ firmness after milking compared with cows without $\mathrm{CM}(P<0.001$, Table 2) on all days. Besides the effect of $\mathrm{CM}(P<$ $0.001), \Delta$ firmness was affected by parity $(P=0.016)$. An effect of continuous milk yield $(P=0.960)$ and DIM $(P=0.513)$ on udder firmness was not observed. Similar results were generated by the re-fitted model in which $\mathrm{CM}(P<0.001)$ and parity $(P=0.025)$, but not continuous milk yield $(P=0.260)$, DIM $(P=0.436)$, or Gram staining characteristics $(P=0.330)$ affected udder firmness.

Cows suffering from severe $\mathrm{CM}$ had a $\Delta$ firmness that was $2.220 \mathrm{~kg}$ higher $(P<0.001)$ compared with cows with mild to moderate CM (Figure 6). Cows not clinically cured showed a higher $\Delta$ firmness of 0.560 $\mathrm{kg}$ compared with that in cured cows $(P<0.001)$. An effect of parity $(P=0.140)$ and bacteriological cure $(P$ $=0.262)$ on udder firmness did not exist.

$\log _{10}$ SCC in quarters with CM $(\mathrm{n}=45)$ was higher compared with quarters without $\mathrm{CM}(\mathrm{n}=235, P<$ 0.001 ) and decreased over time (Figure 7). Parity had a negligible effect on SCC $(P=0.094)$.

\section{DISCUSSION}

The objective of our study was to evaluate if udder firmness can be used to detect CM. Some efforts had been undertaken to evaluate symptoms of mastitis others than abnormalities in the milk such as measuring increased radiated heat emitted by the udder skin

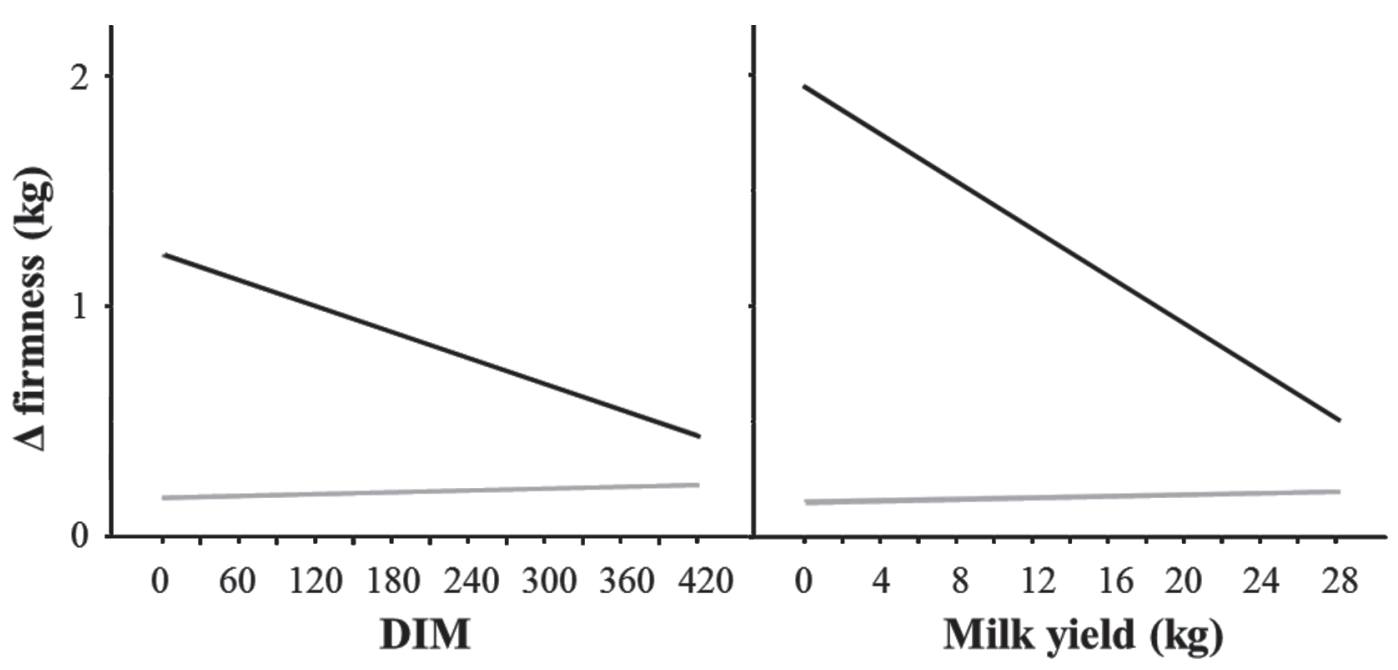

Figure 5. Effect of clinical mastitis $(\mathrm{CM})$, and the interaction with DIM and continuous milk yield per day $(\mathrm{kg})$ in cows without CM $(\mathrm{n}=$ 95, gray line) and cows with CM $(\mathrm{n}=45$, black line) on the difference of udder firmness between both hind quarters $(\Delta$ firmness, $\mathrm{kg})$. Udder firmness was measured with a dynamometer after milking. An interaction existed between CM and DIM $(P=0.008)$, and CM and continuous milk yield per day $(P=0.025)$. The interactions between CM and DIM and CM and continuous milk yield are plotted using mean milk yield $(30 \mathrm{~kg})$ and mean DIM $(160 \mathrm{~d})$, respectively. Values of $\Delta$ firmness shown were generated by a generalized mixed model. 


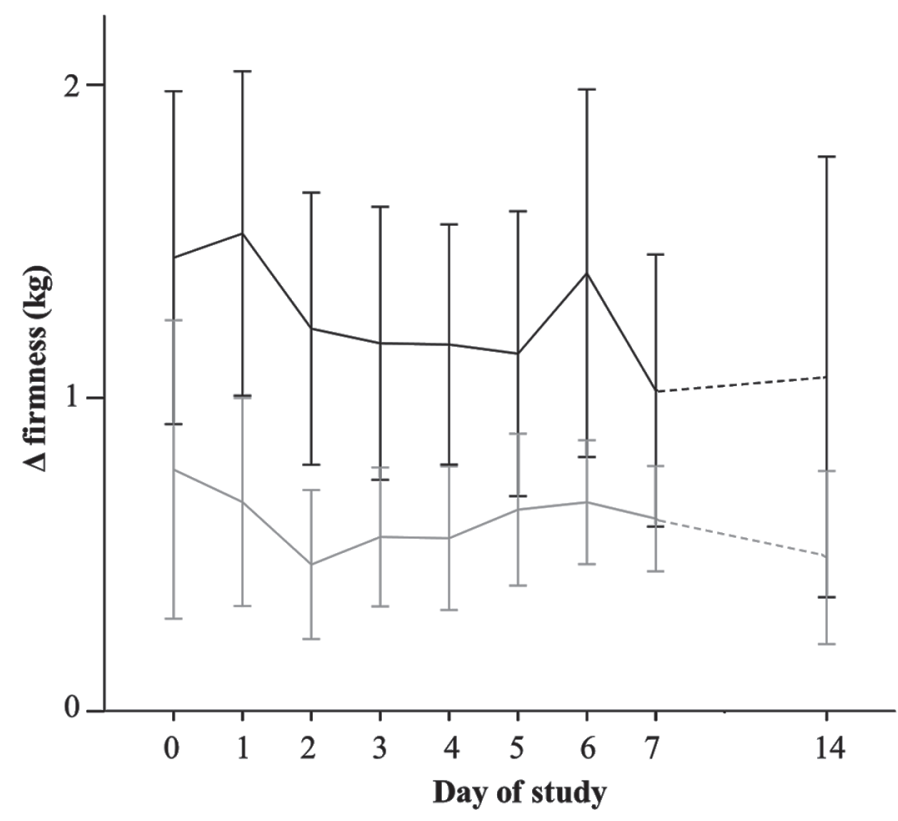

Figure 6. Difference of udder firmness between both hind quarters ( $\Delta$ firmness, $\mathrm{kg})$ in cows with mild to moderate $(\mathrm{n}=24$, gray line) or severe clinical mastitis $(\mathrm{n}=21$, black line) within $14 \mathrm{~d}$ after mastitis was diagnosed. Values of $\Delta$ firmness shown were generated by a linear mixed-model. Error bars represent SEM. via infrared thermography (Hovinen et al., 2008; Polat et al., 2010). Also, changes in pain sensitivity in the course of a CM were measured using a pressure algometer (Fitzpatrick et al., 2013). This device measured the maximum pressure in kilograms of force that could be applied to an udder quarter until the observer could not press any further or the animal had an avoidance reaction to the pressure. Thus, in contrast to our study using an increase in firmness to detect CM, they used pain as a main symptom for a CM. To our knowledge, only preliminary evidence (Rees et al., 2013) has been presented on udder firmness as a criterion to diagnose CM using a validated device. Studies using this device were carried out only in healthy cows (e.g., Bertulat et al., 2013) but not in cows with mastitic quarters. Furthermore, only 3 previous studies used the dynamometer in healthy lactating cows (Bertulat et al., 2013; Rees et al., 2013, 2014). Thus, information is lacking on defined udder firmness ranges for normal and inflamed quarters.

\section{Milk Samples and Cure}

The relationship between bacteriological cure and clinical cure was moderate. In bacteriologically cured cases, $73 \%$ (16 out of 22 cows) also showed clinical cure,

Table 2. Least squares means (and $95 \%$ CI) of difference in udder firmness between both hind quarters $(\mathrm{kg}$ ) in cows without $(\mathrm{n}=95)$ and with $(\mathrm{n}=45)$ clinical mastitis measured with a dynamometer after milking on a measuring point located in the horizontal and vertical center of each udder quarter ${ }^{1}$

\begin{tabular}{|c|c|c|c|}
\hline \multirow[b]{2}{*}{ Item } & \multicolumn{2}{|c|}{ Clinical mastitis } & \multirow[b]{2}{*}{$P$-value ${ }^{2}$} \\
\hline & No & Yes & \\
\hline \multicolumn{4}{|c|}{ Day of study } \\
\hline 0 & $\begin{array}{l}0.073 \\
(0.056 \text { to } 0.096)\end{array}$ & $\begin{array}{l}0.445 \\
(0.263 \text { to } 0.751)\end{array}$ & $<0.001$ \\
\hline 1 & $\begin{array}{l}0.079 \\
(0.063 \text { to } 0.096)\end{array}$ & $\begin{array}{l}0.596 \\
(0.392 \text { to } 0.906)\end{array}$ & $<0.001$ \\
\hline 2 & $\begin{array}{l}0.083 \\
(0.065 \text { to } 0.106)\end{array}$ & $\begin{array}{l}0.363 \\
(0.218 \text { to } 0.606)\end{array}$ & $<0.001$ \\
\hline 3 & $\begin{array}{l}0.066 \\
(0.051 \text { to } 0.087)\end{array}$ & $\begin{array}{l}0.469 \\
(0.300 \text { to } 0.731)\end{array}$ & $<0.001$ \\
\hline 4 & $\begin{array}{l}0.053 \\
(0.040 \text { to } 0.070)\end{array}$ & $\begin{array}{l}0.410 \\
(0.244 \text { to } 0.689)\end{array}$ & $<0.001$ \\
\hline 5 & $\begin{array}{l}0.066 \\
(0.049 \text { to } 0.089)\end{array}$ & $\begin{array}{l}0.462 \\
(0.292 \text { to } 0.731)\end{array}$ & $<0.001$ \\
\hline 6 & $\begin{array}{l}0.067 \\
(0.052 \text { to } 0.086)\end{array}$ & $\begin{array}{l}0.551 \\
(0.353 \text { to } 0.862)\end{array}$ & $<0.001$ \\
\hline 7 & $\begin{array}{l}0.076 \\
(0.061 \text { to } 0.094)\end{array}$ & $\begin{array}{l}0.499 \\
(0.341 \text { to } 0.731)\end{array}$ & $<0.001$ \\
\hline 14 & $\begin{array}{l}0.084 \\
(0.066 \text { to } 0.180)\end{array}$ & $\begin{array}{l}0.340 \\
(0.218 \text { to } 0.530)\end{array}$ & $<0.001$ \\
\hline$P$-value ${ }^{3}$ & 0.182 & $<0.001$ & - \\
\hline
\end{tabular}

${ }^{1}$ Values are from a linear mixed-model ANOVA accounting for fixed effects of clinical mastitis and parity and a random effect of cow with day as the repeated measure. Values were $\log _{10}$ transformed, but back-transformed LSM $(95 \%$ CI) are presented here.

${ }^{2} P$-value for comparison of udder firmness in healthy cows and cows with mastitis on a given study day.

${ }^{3} P$-value for comparison of udder firmness on all study days for healthy cows and cows with mastitis, respectively. 


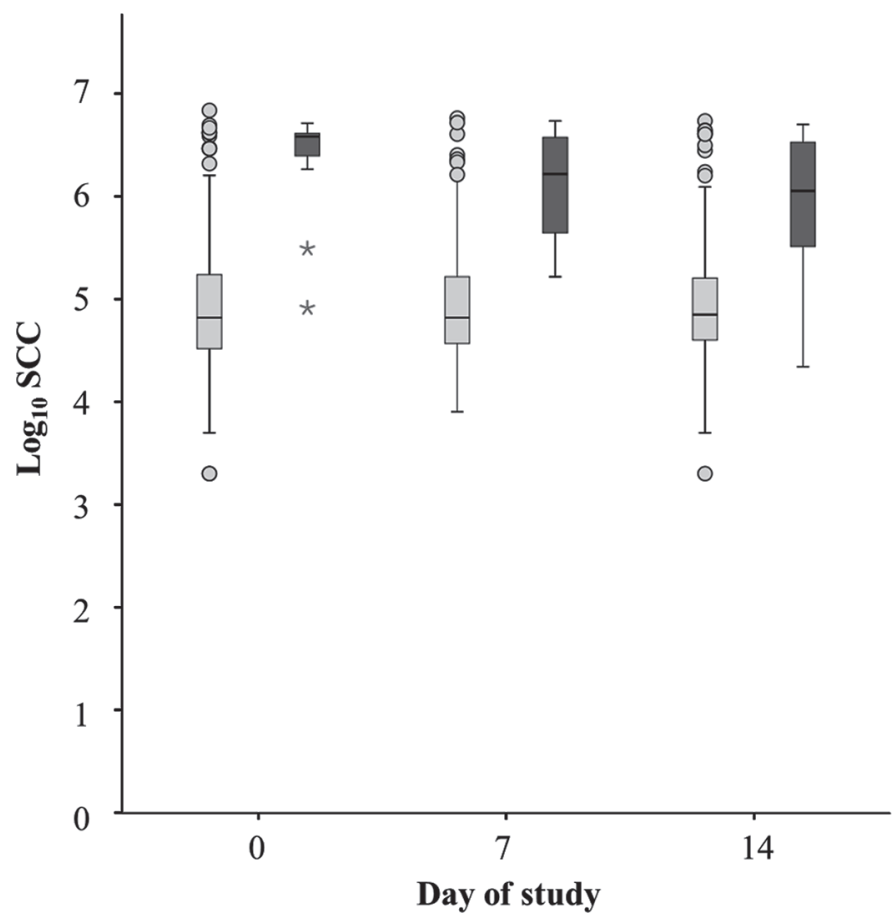

Figure 7. $\log _{10}$ SCC for each study day in quarters without (n $=235$, light gray bars) and with clinical mastitis $(\mathrm{n}=45$, dark gray bars). The heavy black line inside each box marks the median; the bottom and top of the boxes are the first and third quartiles; whiskers end at the smallest and largest statistical values that are not outliers or extreme values. Circles and asterisks indicate outliers and extreme outliers, respectively.

whereas the bacteriologically noncured cases showed $54 \%$ clinical cure. Similar results were reported by Schukken et al. (2013). The variance in severity and the variety of pathogens involved could be an explanation as different pathogens lead to different cure rates (Schukken et al., 2013).

Although clinical cure rates were similar in cows suffering from mild to moderate $\mathrm{CM}$ and severe $\mathrm{CM}$, only $25 \%$ (6 out of 24 ) of cows with severe CM compared with $52 \%$ (11 out of 21 ) of cows with mild to moderate CM were bacteriologically cured. The frequency distribution of bacteriologically negative, gram-positive, and gram-negative samples, however, were similar in cases of mild to moderate and severe CM. This finding is similar to previous observations that the probability of bacteriological cure decreases when the cow is systemically ill (Steeneveld et al., 2011).

\section{Udder Firmness}

Overall median firmness $(1.867 \mathrm{~kg}$, IQR: 1.243 to $2.671 \mathrm{~kg}$ ) measured before milking in our study was higher compared with median firmness $(1.373 \mathrm{~kg}$, IQR: 0.996 to $1.845 \mathrm{~kg}$ ) in a previous study (Rees et al.,
2014). In the latter study, however, healthy cows with a lower 305-d milk yield of 8,745 $\pm 2,149 \mathrm{~kg}$ were used compared with a $305-\mathrm{d}$ milk yield of $10,147 \mathrm{~kg}$ in the current study. As udder firmness particularly before milking is influenced by milk yield, we assume the different level of milk yield to result in different udder firmness before milking in these 2 studies. Another study (Rees et al., 2013) found firmer udders (mean udder firmness, IQR: $3.148 \mathrm{~kg}, 2.507$ to $3.869 \mathrm{~kg}$ ) in healthy cows before milking but used all 4 quarters and only a limited sample size $(\mathrm{n}=20)$. Therefore, comparison is critical. In previous studies (Rees et al., 2013, 2014) and the current trial, median milking-induced decrease of udder firmness in healthy quarters was significant. It ranged from $0.763 \mathrm{~kg}$ (IQR: 0.426 to $1.570 \mathrm{~kg}$; Rees et al., 2014) over $1.207 \mathrm{~kg}$ (0.649 to $1.914 \mathrm{~kg}$ ) in our study to $1.950 \mathrm{~kg}$ (1.458 to $2.827 \mathrm{~kg}$; Rees et al., 2013). A decrease in firmness can be explained by drop in pressure due to milking.

Our results clearly indicate that determination of firmness as part of an udder examination to diagnose $\mathrm{CM}$ should be conducted after milking as median udder firmness in quarters with CM $(1.036 \mathrm{~kg}$, IQR: 0.704 to $1.702 \mathrm{~kg}$ ) was significantly higher than in quarters without CM (0.636 kg, IQR: 0.514 to $0.783 \mathrm{~kg}$ ) after milking. This is in line with a previous recommendation (Radostits et al., 2006) describing that clinical examination of the mammary gland is of greatest value when the udder has been recently milked. We assume that the effect of milk filling the udder confounds the difference in firmness due to inflammation before milking.

Second, we tested the effect of measuring point within a quarter to identify the best diagnostic location. Firmness between the 3 locations within a given quarter was compared to determine a potential firmness gradient. Firmness measured before and after milking differed between the 3 locations $(P<0.001)$ both in cows without $(\mathrm{n}=1,848$ and 2,081$)$ and with $\mathrm{CM}(\mathrm{n}=356$ and 399). This finding is in agreement with previous studies (Bertulat et al., 2012). They found, however, the lower measuring point to be the firmest, instead of the middle measuring point as in our study, and assumed Pascal's law (i.e., in fluids, pressure is highest at the lowest level) to be one explanation for this finding. In the study conducted by Bertulat et al. (2012), however, only cows after dry-off were used. It was shown that only 38 to $47 \%$ of the total milk yield is stored within the cistern [i.e., in the lower part of the udder (McKusick et al., 2002)]. When a cow is not milked or recently dried-off, the amount of milked stored in the cistern increases leading to a higher udder firmness in the lower part of the udder (Bertulat et al., 2012). We assume that firmness measured in the upper point primarily represents connective tissue of the suspensory apparatus 
and firmness of the lower measuring point is biased by the proximity to the gland cistern, which is a soft structure due to its cavernous character. Interestingly, our results indicate that difference in udder firmness between the middle and lower measuring point within each quarter provides diagnostic value for the detection of inflammation as quarters with CM showed no difference in firmness after milking between these 2 measuring points $(P=0.257)$. This could be explained by an udder edema as one clinical sign associated with CM (Fitzpatrick et al., 2013). This edema is likely to sink to the lowest part of the udder, resulting in an increased firmness on the lower measuring point. Regardless of the reasons for firmness distribution, however, our data as well as previously published data (Bertulat et al., 2012) emphasize the importance of a defined measuring point for a repeatable measurement.

As the middle measuring point was already used in previous studies addressing udder firmness (Tucker et al., 2009; Bertulat et al., 2013) and re-calculating ROC curves for the lower measuring point yielded similar results compared with the middle measuring point, we used firmness values assessed on the middle measuring point at $\mathrm{d} 0$ to evaluate differences in udder firmness between quarters without and with CM. Firmness in quarters with $\mathrm{CM}$ was higher $(P<0.001)$ compared with quarters without CM. Firmness of healthy quarters did not differ when considered either as a dependent (within one healthy cow, $P=0.369$ ) or as an independent variable (throughout all enrolled cows without and with CM, $P=0.419)$. This demonstrates that the udder tissue of a given quarter is not affected by inflammation of the neighboring quarter. Thus, an increase of udder firmness of the quarter with CM did not affect the firmness of its healthy neighboring quarter. Also, udder firmness of healthy quarters did not differ. Our data indicate that a healthy quarter next to a quarter with CM could be used as a negative control. Therefore, we calculated $\Delta$ firmness as a parameter on the cow level to reduce data clustering and provided a diagnostic approach by using the cow as her own negative control.

After milking, cows with CM had a higher $\Delta$ firmness compared with healthy cows $(P<0.001)$ due to one firmer udder quarter with CM. The interaction between CM and DIM indicated that the difference of $\Delta$ firmness between cows without and with CM decreased when DIM increased. A high proportion of severe CM occurs in the early lactation (Ruegg, 2011). In our study, cows with severe CM had a firmer udder than cows with mild to moderate $\mathrm{CM}$ as discussed below. Average DIM of cows with severe CM and mild to moderate $\mathrm{CM}$ was $133 \pm 101$ and $166 \pm 103$, respectively. This may have resulted in the lower difference of udder firmness in late lactation. The interaction between CM and continuous milk yield per day indicated that the difference of $\Delta$ firmness between cows without and with $\mathrm{CM}$ was greater when milk yield was low. Cows with $\mathrm{CM}$ and cows with severe CM (i.e., cows with a high $\Delta$ firmness) had a significantly lower milk yield than healthy cows $(P<0.001)$ and cows with mild to moderate CM $(P=0.045)$, respectively. This could have caused the high difference in udder firmness when milk yield was low. Further evaluation of factors potentially influencing udder firmness revealed that udder firmness of primiparous cows was only increased by CM. This could be explained by the smaller udder shape of young cows (Fossing et al., 2006) and that parenchymal and alveolar cells in the udder grow until fifth or sixth parity (Klaas et al., 2004). Furthermore, udders of primiparous cows are not yet influenced by CM in previous lactations. Udder firmness of multiparous cows was affected by CM $(P<0.001)$, milk yield per day $(P<0.001)$, and DIM $(P<0.001)$. Our results might be explained by the different shape of lactation curves (Horan et al., 2005) and the decrease of secretory tissue during the declining phase of lactation (Klaas et al., 2004) resulting in higher variation of milk yield within one lactation in multiparous cows and in a softer udder in the course of one lactation, respectively. Interestingly, continuous milk yield per day influenced udder firmness even after milking in multiparous cows. It had been described that udder tissue will be more active producing milk, especially at the beginning of the lactation as milk will be stored in ducts and cisterns, leading to a harder udder even when examined immediately after milking (Fossing et al., 2006).

We had expected gram-negative pathogens to cause firmer udders due to the well-known fact that the majority of cases with severe symptoms are caused by gram-negative pathogens (Oliveira et al., 2013). Furthermore, changes in echogenicity in cows with CM were more pronounced by some gram-negative pathogens (e.g., Fasulkov, 2012). Interestingly, we could not confirm those findings with our data set, which might be due to the relatively small number of $\mathrm{CM}$ caused by gram-negative pathogens $(\mathrm{n}=10)$. In our study, $54.4 \%$ of milk samples from cows showing mild to moderate symptoms of CM were bacteriologically negative. Similar results were found in a previous study (Oliveira et al., 2013). In their study, $57.9 \%$ of milk samples from cows showing mild symptoms of CM (i.e., only the milk was abnormal but the mammary gland was normal) were bacteriologically negative. This could further explain the lack of association of Gram staining characteristics with udder firmness in our study. A high percentage of cows in our study had bacteriologically negative milk samples $(69.2 \%$ of cows without CM and 
$53.1 \%$ of cows with $\mathrm{CM}$ ), and therefore, could have shown only abnormal milk but a normal gland. Symmetry of hind quarters did not affect $\Delta$ firmness. Eightytwo out of 95 cows without CM $(86.3 \%)$ and only 7 out of 45 cows with CM (15.6\%), however, had symmetric hind quarters $(P<0.001)$.

\section{Thresholds of Udder Firmness}

We set out to use udder firmness as a cow-side indicator for CM by establishing objective firmness thresholds for the differentiation between cows without and with CM. The ROC curves were used to determine the diagnostic value of udder firmness measurements for detecting CM, which was defined by visible abnormalities in the milk according to the International Dairy Federation (IDF, 1999). The area under the ROC curve of our study ranged from 0.722 (primiparous cows) to 0.817 (multiparous cows), indicating that $\Delta$ firmness provides a very accurate test (Swets, 1988; Ospina et al., 2010). A threshold of $>0.282 \mathrm{~kg}$ and $>0.425 \mathrm{~kg}$ $\Delta$ firmness provided the best combination of sensitivity and specificity and identified $64.3 \%$ of primiparous cows and $62.5 \%$ of multiparous cows as truly suffering from CM. The positive predictive value (i.e., the probability that CM was present when the test was positive) using these thresholds was higher for multiparous cows (90.9\%) compared with primiparous cows (69.2\%). Sensitivity of the method is of particular importance in mastitis detection (Pyörälä, 2003) as improved sensitivity of a mastitis detection technique improves herd udder health (Kamphuis et al., 2010). On the other hand, the evaluation method should be highly specific for healthy quarters to avoid separating normal milk (Hovinen and Pyörälä, 2011) and potentially treating healthy cows with antibiotics. Our firmness thresholds provided either a high sensitivity or high specificity, but could not achieve both of the target values set by the ISO (2007). The trade-off between sensitivity and specificity had already been described in a systematic review (Rutten et al., 2013) for sensor studies addressing mastitis detection. None of the studies $(\mathrm{n}=31)$ mentioned in this review met the ISO/FDIS 20966 limit of sensitivity and specificity (ISO, 2007). Considering the range of the positive predictive value, the diagnostic value of udder firmness (69.2 to 93.1), however, was equivalent to milk thermography (78.8 to 100 ; Polat et al., 2010) and even better than, for example, the electrical conductivity of milk (7 to 16 ; Hovinen and Pyörälä, 2011).

Besides the above-mentioned algometer (Fitzpatrick et al., 2013), our study is the first to describe a measuring device evaluating a symptom of the gland itself to diagnose $\mathrm{CM}$ in addition to milk-based detection such as cell count or conductivity. Combining both approaches to detect $\mathrm{CM}$ would be closer to the definition of this disease by the IDF (1999) characterizing CM as visible abnormalities in the milk, udder, or both. Also, combining several indicators for CM could improve detection of CM (Hovinen and Pyörälä, 2011). Further research, however, is warranted to validate such an approach for mastitis detection.

\section{Udder Firmness Within 2 Wk After Diagnosis}

We followed the cows for $14 \mathrm{~d}$ after the initial diagnosis of CM. Surprisingly, $\Delta$ firmness of cows with CM was higher compared with healthy cows even $14 \mathrm{~d}$ after $\mathrm{CM}$ had been diagnosed. Hence, infected quarters were firmer until the end of the observation period indicating a healing process of over 2 wk. Day of study had no effect on udder firmness. These results are consistent with recently published data suggesting that the recovery period after a CM expressed as reduced milk yield, elevated lactate dehydrogenase activity, lower milking frequency, and elevated inter-quarter yield ratio continued for weeks after the antibiotic treatment (Fogsgaard et al., 2015). Twenty-four and 30 out of 45 quarters with CM showed a normal milk on d 7 and 14, respectively, but were considerably firmer than healthy quarters. This discrepancy could be explained by the reaction of the connective udder tissue toward sustained immune response such as release of chemokines (Wellnitz and Bruckmaier, 2012) leading to a firmer udder even after return to a normal appearance of milk. Second, a sensitivity of $80 \%$ for visual inspection of milk for CM was reported (Hillerton, 2000). Hence, cows with minimum abnormalities of the milk could have been judged as healthy by the milking personnel. As cows with $\mathrm{CM}$ were considered as healthy cows in the statistical model as soon as they were clinically cured, they potentially could have biased the difference in udder firmness between cows without and with CM throughout the $14 \mathrm{~d}$. Therefore, we removed cows with CM that had normal milk and re-fitted the mixed models. This approach, however, did not change the results, indicating the absence of a bias.

As on d 0, parity affected udder firmness on all study days $(P=0.016)$. Regardless of $\mathrm{CM}$, multiparous cows had a higher $(P=0.023) \Delta$ firmness compared with primiparous cows on all study days. As mentioned before, udder tissue of primiparous cows is not fully developed and is more uniform compared with udder tissue of multiparous cows (Klaas et al., 2004; Fossing et al., 2006). Moreover, firmness is not biased by cases of CM in previous lactations. Similar to udder firmness on d 0, Gram stain characteristics did not affect udder firmness during the first 2 wk after $\mathrm{CM}$ diagnosis 
$(P=0.330)$. Severity of CM influenced udder firmness throughout the $14 \mathrm{~d}$ as cows with mild to moderate CM showed lower $\Delta$ firmness compared with cows with severe CM. This indicates that cows with systemic signs of a CM also suffer from a firmer udder.

The decrease of SCC in quarters with $\mathrm{CM}$ within the $14 \mathrm{~d}$ after CM diagnosis is in line with a previous study (Oliveira et al., 2013). The fact that SCC of quarters with CM were higher than SCC of quarters without $\mathrm{CM}$ throughout the $14 \mathrm{~d}$ indicates a recovery period continuing longer than $2 \mathrm{wk}$.

\section{Study Limitations}

Firmness of front udder quarters was not studied for practical reasons. As cows stood side by side in the milking parlor, reaching the front quarters with the dynamometer was not possible. Additional studies are warranted to evaluate if udder firmness of front quarters could be used for CM diagnosis as well.

In all studies investigating udder health and mastitis, several biases might have influenced the results (Dufour et al., 2012). First, the investigator in our study could not be blinded to the udder health status of the cow due to logistical limitations. We considered it unlikely that the nonblinded investigator affected the outcome of the study because measurements were conducted with a digital device (dynamometer) and a standard operating procedure (Bertulat et al., 2012) was implemented. As only a limited number of $\mathrm{CM}$ cases $(\mathrm{n}=45)$ from one herd was included, the study population may not represent all variations and clinical signs of $\mathrm{CM}$ (Hovinen and Pyörälä, 2011). Use of different drugs for the treatment of CM potentially could have biased udder firmness. Future studies should control for this factor.

The dynamometer could be used easily on a daily basis. After training of the observer, measurements show good repeatability (Bertulat et al., 2012; Rees et al., 2014). It remains unclear if udder firmness can be used as a predictive value for the prognosis of a CM. Also, further research is warranted to evaluate potential confounders such as incomplete emptying of the udder after milking (Hovinen and Pyörälä, 2011). It would be interesting to determine to what extent udder firmness measured by a dynamometer could improve in-line detection of CM in automatic milking systems. Whether the firmness of front quarters could likewise serve as a diagnostic tool also needs to be studied. In addition, a more practical approach for diagnosing CM such as manual palpation could be included in future studies, especially because a palpation scoring system was demonstrated to have good within-observer repeatability (Rees et al., 2014).

\section{CONCLUSIONS}

Assessing udder firmness with a dynamometer is a useful tool to distinguish between healthy and inflamed quarters. To diagnose CM, udders of cows should be examined after milking in the middle or lower part of a given udder quarter. A $\Delta$ firmness threshold of 0.282 $\mathrm{kg}$ for primiparous and of $0.425 \mathrm{~kg}$ for multiparous cows should be used to reduce bias by parity. Quarters with CM were firmer compared with healthy quarters even $14 \mathrm{~d}$ after CM had been diagnosed, indicating a recovery period longer than $2 \mathrm{wk}$.

\section{ACKNOWLEDGMENTS}

A. Rees was partly funded by Tiergyn Berlin e.V. (Berlin, Germany). The authors thank Ceva Santé Animal (Libourne, France) for providing the dynamometer. We also thank the participating farm. In particular, we thank the milkers as well as the farm staff for their fantastic support. Special thanks go to Laura Pieper (Institute for Veterinary Epidemiology and Biostatistics, Freie Universität Berlin, Berlin, Germany) and Sandra Bertulat (Clinic for Animal Reproduction, Freie Universität Berlin).

\section{REFERENCES}

Bertulat, S., C. Fischer-Tenhagen, V. Suthar, E. Möstl, N. Isaka, and W. Heuwieser. 2013. Measurement of fecal glucocorticoid metabolites and evaluation of udder characteristics to estimate stress after sudden dry-off in dairy cows with different milk yields. J. Dairy Sci. 96:3774-3787.

Bertulat, S., C. Fischer-Tenhagen, A. Werner, and W. Heuwieser. 2012 Technical note: Validating a dynamometer for noninvasive measuring of udder firmness in dairy cows. J. Dairy Sci. 95:6550-6556.

Dohoo, I. R., S. W. Martin, and H. Stryhn. 2009. Veterinary Epidemiologic Research. 2nd ed. University of Prince Edward Island, Charlottetown, PEI, Canada.

Dufour, S., I. R. Dohoo, H. W. Barkema, L. DesCôteaux, T. J. DeVries, K. K. Reyher, J. P. Roy, and D. T. Scholl. 2012. Manageable risk factors associated with the lactational incidence, elimination, and prevalence of Staphylococcus aureus intramammary infections in dairy cows. J. Dairy Sci. 95:1283-1300.

Fasulkov, I. R. 2012. Ultrasonography of the mammary gland in ruminants: A review. Bulgarian J. Vet. Med. 15:1-12.

Fitzpatrick, C. E., N. Chapinal, C. S. Petersson-Wolfe, T. J. DeVries, D. F. Kelton, T. F. Duffield, and K. E. Leslie. 2013. The effect of meloxicam on pain sensitivity, rumination time, and clinical signs in dairy cows with endotoxin-induced clinical mastitis. J. Dairy Sci. 96:2847-2856.

Fogsgaard, K. K., P. Løvendahl, T. W. Bennedsgaard, and S. Østergaard. 2015. Changes in milk yield, lactate dehydrogenase, milking frequency, and interquarter yield ratio persist for up to 8 weeks after antibiotic treatment of mastitis. J. Dairy Sci. 98:7686-7698.

Fossing, C., M. Vaarst, H. Houe, and C. Enevoldsen. 2006. Contributions to variability of clinical measures for use as indicators of udder health status in a clinical protocol. Acta Vet. Scand. 48:15.

Hertl, J. A., Y. H. Schukken, D. Bar, G. J. Bennett, R. N. González, B. J. Rauch, F. L. Welcome, L. W. Tauer, and Y. T. Gröhn. 2011. The effect of recurrent episodes of clinical mastitis caused by gram-positive and gram-negative bacteria and other organ- 
isms on mortality and culling in Holstein dairy cows. J. Dairy Sci. 94:4863-4877.

Hertl, J. A., Y. H. Schukken, F. L. Welcome, L. W. Tauer, and Y. T. Gröhn. 2014. Pathogen-specific effects on milk yield in repeated clinical mastitis episodes in Holstein dairy cows. J. Dairy Sci. 97:1465-1480.

Hillerton, J. E. 2000. Detecting mastitis cow-side. Pages 48-53 in Proc. National Mastitis Council 39th Annual Meeting, Atlanta, GA. National Mastitis Council Inc., Madison, WI.

Hogan, J. S., R. N. Gonzales, R. J. Harmon, S. C. Nickerson, S. P. Oliver, J. W. Pankey, and K. L. Smith. 1999. Laboratory Handbook on Bovine Mastitis. Rev. ed. National Mastitis Council Inc., Madison, WI.

Horan, B., P. Dillon, D. P. Berry, P. O'Connor, and M. Rath. 2005 The effect of strain of Holstein-Friesian, feeding system and parity on lactation curves characteristics of spring-calving dairy cows. Livest. Prod. Sci. 95:231-241.

Hovinen, M., and S. Pyörälä. 2011. Invited review: Udder health of dairy cows in automatic milking. J. Dairy Sci. 94:547-562.

Hovinen, M., J. Siivonen, S. Taponen, L. Hänninen, M. Pastell, A.-M. Aisla, and S. Pyörälä. 2008. Detection of clinical mastitis with the help of a thermal camera. J. Dairy Sci. 91:4592-4598.

IDF (International Dairy Federation). 1999. Suggested interpretation of mastitis terminology. Pages 3-26 in Bull. Int. Dairy Fed. No. 338.

ISO (International Organization for Standardization). 2007. Automatic milking systems-Requirements and testing. ISO 20966. Annex C: Example of methods of evaluating detection systems for milk deemed as abnormal due to blood or changes in homogeneity. ISO, Geneva, Switzerland.

Kamphuis, C., H. Mollenhorst, J. A. P. Heesterbeek, and H. Hogeveen. 2010. Detection of clinical mastitis with sensor data from automatic milking systems is improved by using decision-tree induction. J. Dairy Sci. 93:3616-3627.

Klaas, I. C., C. Enevoldsen, M. Vaarst, and H. Houe. 2004. Systematic clinical examinations for identification of latent udder health types in Danish dairy herds. J. Dairy Sci. 87:1217-1228.

Machado, V. S., M. L. S. Bicalho, E. B. S. Meira Junior., R. Rossi, B. L. Ribeiro, S. Lima, T. Santos, A. Kussler, C. Foditsch, E. K. Ganda, G. Oikonomou, S. H. Cheong, R. O. Gilbert, and R. C. Bicalho. 2014. Subcutaneous immunization with inactivated bacterial components and purified protein of Escherichia coli, Fusobacterium necrophorum and Trueperella pyogenes prevents puerperal metritis in Holstein dairy cows. PLoS One 9:e91734.

McKusick, B. C., D. L. Thomas, Y. M. Berger, and P. G. Marnet 2002. Effect of milking interval on alveolar versus cisternal milk accumulation and milk production and composition in dairy ewes. J. Dairy Sci. 85:2197-2206.

Oliveira, L., C. Hulland, and P. L. Ruegg. 2013. Characterization of clinical mastitis occurring in cows on 50 large dairy herds in Wisconsin. J. Dairy Sci. 96:7538-7549.

Oliver, S. P., S. E. Murinda, and B. M. Jayarao. 2011. Impact of antibiotic use in adult dairy cows on antimicrobial resistance of veterinary and human pathogens: A comprehensive review. Foodborne Pathog. Dis. 8:337-355

Ospina, P. A., D. V. Nydam, T. Stokol, and T. R. Overton. 2010. Evaluation of nonesterified fatty acids and $\beta$-hydroxybutyrate in transition dairy cattle in the northeastern United States: Critical thresholds for prediction of clinical diseases. J. Dairy Sci. 93:546554 .
Pol, M., and P. L. Ruegg. 2007. Treatment practices and quantification of antimicrobial drug usage in conventional and organic dairy farms in Wisconsin. J. Dairy Sci. 90:249-261.

Polat, B., A. Colak, M. Cengiz, L. E. Yanmaz, H. Oral, A. Bastan, S. Kaya, and A. Hayirli. 2010. Sensitivity and specificity of infrared thermography in detection of subclinical mastitis in dairy cows. J. Dairy Sci. 93:3525-3532.

Pyörälä, S. 2003. Indicators of inflammation in the diagnosis of mastitis. Vet. Res. 34:565-578.

Radostits, O. M., C. C. Gay, K. W. Hinchcliff, and P. D. Constable. 2006. Diseases of the mammary gland. Pages $672-762$ in Veterinary Medicine, A Textbook of the Diseases of Cattle, Horses, Sheep, Pigs and Goats. 10th ed. Saunders Ltd., Edinburgh, UK.

Rees, A., C. Fischer-Tenhagen, and W. Heuwieser. 2013. Comparison of udder firmness of cows affected by mastitis and cows not affected. Page 154 in Proc. Buiatrissima 8th ECBHM Symposium, Bern, Switzerland.

Rees, A., C. Fischer-Tenhagen, and W. Heuwieser. 2014. Evaluation of udder firmness by palpation and a dynamometer. J. Dairy Sci. 97:3488-3497.

Rosenberger, G., G. Dirksen, H.-D. Gründer, M. Stöber, and E. Grunert. 1990. Clinical Examination of Cattle. Paul Parey, Berlin, Germany.

Ruegg, P. L. 2011. Managing mastitis and producing quality milk. Pages 207-232 in Dairy Production Medicine. 1st ed. John Wiley and Sons, Hoboken, NJ.

Rutten, C. J., A. G. J. Velthuis, W. Steeneveld, and H. Hogeveen. 2013. Invited review: Sensors to support health management on dairy farms. J. Dairy Sci. 96:1928-1952.

Schukken, Y. H., M. J. Zurakowski, B. J. Rauch, B. Gross, L. L. Tikofsky, and F. L. Welcome. 2013. Noninferiority trial comparing a first-generation cephalosporin with a third-generation cephalosporin in the treatment of nonsevere clinical mastitis in dairy cows. J. Dairy Sci. 96:6763-6774.

Steeneveld, W., T. van Werven, H. W. Barkema, and H. Hogeveen. 2011. Cow-specific treatment of clinical mastitis: An economic approach. J. Dairy Sci. 94:174-188.

Swets, J. A. 1988. Measuring the accuracy of diagnostic systems. Science 240:1285-1293.

Swinkels, J. M., A. Hilkens, V. Zoche-Golob, V. Krömker, M. Buddiger, J. Jansen, and T. J. G. M. Lam. 2015. Social influences on the duration of antibiotic treatment of clinical mastitis in dairy cows. J. Dairy Sci. 98:2369-2380.

Thomson, K., M. Rantala, M. Hautala, S. Pyörälä, and L. Kaartinen. 2008. Cross-sectional prospective survey to study indication-based usage of antimicrobials in animals: Results of use in cattle. BMC Vet. Res. 4:15.

Thrusfield, M., C. Ortega, I. de Blas, J. P. Noordhuizen, and K. Frankena. 2001. Win EPISCOPE 2.0: Improved epidemiological software for veterinary medicine. Vet. Rec. 148:567-572.

Trevisi, E., A. Zecconi, S. Cogrossi, E. Razzuoli, P. Grossi, and M. Amadori. 2014. Strategies for reduced antibiotic usage in dairy cattle farms. Res. Vet. Sci. 96:229-233.

Tucker, C. B., S. J. Lacy-Hulbert, and J. R. Webster. 2009. Effect of milking frequency and feeding level before and after dry off on dairy cattle behavior and udder characteristics. J. Dairy Sci. 92:3194-3203

Wellnitz, O., and R. M. Bruckmaier. 2012. Review: The innate immune response of the bovine mammary gland to bacterial infection. Vet. J. 192:148-152. 